\title{
People v. Barraza: California's Latest Attempt to Accommodate an Objective Theory of Entrapment
}

The California Supreme Court has explicitly adopted the objective theory of entrapinent in People v. Barraza, ${ }^{1}$ grounding the defense on the likelihood that police undercover tactics would induce a hypothetical "normally law-abiding person" to commit the crime with which the defendant is charged. For the past twenty years, California courts have struggled with a "hybrid approach" to entrapment which atteinpted unsuccessfully to reconcile the opposing subjective and objective views of the defense. ${ }^{2}$ This attempt was doomed from the outset because the two theories are logically incompatible. Both seek to prevent the government from manufacturing crime. The subjective theory will not find entrapment if the suspect was "predisposed" to commit the crime regardless of the government's conduct, while the objective theory allows the entrapment defense if the government's conduct falls below certain generalized standards, regardless of the suspect's predisposition. California's efforts to combine these contradictory viewpoints have produced confused, often unjust caselaw, and People v. Barraza is the supreme court's long overdue attempt to bring coherence to the entrapment doctrine in this state.

Barraza involved a former narcotics addict who testified at his trial that he lielped an undercover agent procure heroin only after the agent had harassed him so zealously that he feared he would lose his job. Holding that the trial court committed reversible error when it refused to instruct the jury on entrapment, the supreine court announced a new test expressing a nore objective approach to entrapinent. Under this test the jury must determine whether the conduct of the law enforcement agent was likely to induce a normally law-abiding

1. 23 Cal. 3d 675, 591 P.2d 947, 153 Cal. Rptr. 459 (1979) (Mosk, J.) (5-1-1 decision).

2. The terms "subjective" and "objective" are used in the entrapment context much as they are used in contracts. An objective assessment decides the issue without refercnce to the individual suspect, applying generalized rules for the propriety of police inducements drawn from the probable response of a hypothetical person. The subjective test varies according to each suspect's individual state of mind, and sets no general standards for the permissibility of police conduct. Although the use of these terms in connection with entrapment has been criticized, see Park, The Entrapment Controversy, 60 MiNN. L. Rev. 163, 165 n.2 (1976); Tanford, Entrapment: Guidelines for Counsel and the Courts, 13 CRIM. L. BuLL. 5, 12 (1977), this Note will employ these tcrms as a convenient shorthand for the two doctrines, and without any pretensions that the "objective" test removcs all danger of bias in deciding the issue. 
person to commit the offense. ${ }^{3}$

Although the Barraza test is phrased objectively-it judges pohice conduct by its probable effect on a hypothetical person rather than by the particular defendant's state of mind-the court seems unwilling to embrace the objective theory wholeheartedly. The vague "normally law-abiding person" standard will misfocus attention away from the police conduct and may fail to reach cases of governmental overinvolvement in crime which the objective theory has traditionally, and justifiably, condemned. The court inexphicably leaves the entrapinent issue with the jury, contrary to all prior objective formulations of the defense. Finally, Barraza admits evidence bearing on predisposition, thereby injectmg subjective elements into a supposedly objective test. The court could have avoided these problems by taking a completely objective approach, focusing directly on the likelihood that the police conduct would manufacture crime.

\section{I}

\section{THE CASE}

Barraza was charged with two counts of selling heroin, the second of which raised the issue of entrapment. ${ }^{4}$ At his trial, Barraza testified that a female agent had tried repeatedly to contact him at work during the three weeks prior to the sale. He eventually agreed to meet with the agent, fearing that her requests for drugs might cost him his job at the detoxification center where he worked. When they finally inet, she pressured him for over an hour to provide her with heroin, and to end her harrassment he gave her a note introducing her to a herom peddler. ${ }^{5}$ Despite this testimony, ${ }^{6}$ the trial judge refused to give an entrapment instruction, and the jury convicted Barraza on both counts.

On appeal, the supreme court reexamined the entrapment doctrine and rejected the "hybrid" approach taken in California since People $v$. Benford. ${ }^{7}$ Justice Mosk, writing for the majority, noted the recent trend toward the objective theory in state courts and its almost univer-

3. 23 Cal. 3d at $689-90,591$ P.2d at 955,153 Cal. Rptr. at 467.

4. His conviction on the first count was overturned because the trial court gave the jury the provocative "mini-Allen charge" to " "get them off the dime" " when they appeared to be deadlocked. Id. at 682-85, 591 P.2d at 950-52, 153 Cal. Rptr. at 462-64.

5. One of the dissenting opmions notes, although the majority opimion does not, that this dealer was Barraza's wife. Id. at 694, 591 P.2d at 958, 153 Cal. Rptr. at 470 (Clark, J., dissenting).

6. This testimony was not uncontradicted. The agent testified that the defendant hesitated only because he could not afford to go back to jail, and that he provided the note as soon as she convinced him that she was not an agent. Id. at 680, 591 P.2d at 949, 153 Cal. Rptr. at 461.

7. 53 Cal. $2 d$ 1, 345 P.2d 928 (1959). This reexamination was not strictly required to decide the case, however, because the court found substantial evidence of entrapment under either test and so would remand for an entrapment instruction. $23 \mathrm{Cal} .3 \mathrm{~d}$ at $691,591 \mathrm{P} .2 \mathrm{~d}$ at 956, $153 \mathrm{Cal}$. Rptr. at 468. 
sal favor among legal commentators. Finding the objective approach to be more consistent with "the underlying purpose of the entrapment defense," Mosk proposed a new test in California that would focus on whether the conduct of the law enforcennent officer was likely to induce a "normally law-abiding person" to commit the offense.

Mosk explaimed that pohice conduct which merely provided an opportunity to commit the crime would not constitute entrapment, because the "normally law-abiding person" would be able to resist such a temptation. It would be imperimssible, however, for the police to pressure a suspect by badgering or cajoling him-even the normally lawabiding person might succumb to such tactics. ${ }^{9}$ Mosk offered two general primciples for determining the propriety of police conduct: it must not generate im the normally law-abiding person a motive other than ordimary criminal intent (i.e., sympathy or fear), and it must not make the crime unusually attractive to a normally law-abiding person. ${ }^{10}$

In applymg these primciples, the factfinder caimot view the police conduct in a vacuum. The normally law-abiding person must be placed in the circuinstances of the case, imcluding the "transactions preceding the offense, the suspect's response to the inducements of the officer, the gravity of the crime, and the difficulty of detecting instances of its commission." 11 The suspect's character and predisposition are, however, irrelevant under the new rule.

Mosk concluded that Barraza had imtroduced sufficient evidence of entrapment to merit a sua sponte jury instruction on the defense. Entrapinent, "in view of its potentially substantial effect on the issue of guilt," remains a jury question under the new test. ${ }^{12}$ Finally, the court decided that Barraza would not apply retroactively, because the primary goal of the objective theory is to deter future police misconduct. ${ }^{13}$

8. $23 \mathrm{Cal}$. $3 \mathrm{~d}$ at $689-90,591$ P.2d at $955,153 \mathrm{Cal}$. Rptr. at 467.

9. Id. at 690,591 P.2d at $955,153 \mathrm{Cal}$. Rptr. at 467.

10. Id.

11. Id. at 690-91, 591 P.2d at 955-56, 153 Cal. Rptr. at 467-68.

12. Id. at 691 n.6, 591 P.2d at 956 n.6, 153 Cal. Rptr. at 468 n.6. Ironically, only two members of the majority actually favor leaving entrapment with the jury. See note 67 infra. Their votes, however, coupled with those of the dissenting, subjeetively imclined justiees, comprise a new majority which follows the subjective theory on this issue.

13. The ramifications of this decision are apparent in People v. Mclntire, 23 Cal. 3d 742, 591 P.2d 527, 153 Cal. Rptr. 237 (1979), a later California Supreme Court entrapment decision applying pre-Barraza subjective criteria in a very interesting factual setting. For a discussion of the McIntire case, see Case-m-Brief, People v. McIntire, 68 CALIF. L. Rev. 764. 
II

\section{LEGAL BACKGROUND}

\section{A. Federal Cases}

Deceptive police tactics are a natural response to the simple fact that no one files a complaint about most victimless crimes. The government cannot usually investigate and prosecute these crimes, therefore, unless its agent is somehow involved in the transaction. If the agent simply offers to buy contraband or pay for an illegal favor, he is probably just providing an opportunity to commit the crime and there is no entrapment. A reluctant suspect may, however, prompt the agent to resort to more persuasive tactics to complete the deal. As the conduct becomes more extreme, a danger arises that the agent is entrapping the suspect into committing the crime. Entrapment occurs at that indefinite point when the government begins to nanufacture crime rather than investigate it. ${ }^{14}$

Courts have recognized the need for an entrapment defense to curb possible governmental manufacturing of crime ever since the Prohibition era, ${ }^{15}$ but they have been unable to reach a consensus regarding its theoretical basis or practical application. ${ }^{16}$ On these issues there are two distinct schools of thouglit which, while sometimes reaching the same result, approacli entrapment froin widely divergent perspectives.

Chief Justice Hughes promulgated the subjective theory of entrapment, which still prevails in all federal and nost state courts. Sorrells $v$. United States ${ }^{17}$ arose during Prohibition when a government agent finally induced a whiskey sale only after he had made three separate requests for hquor and ingratiated himself with the suspect by trading old war stories. Hughes argued that it could not have been Congress' intention to enforce its laws by sending government agents to lure "otherwise innocent" people into committing a crime. People could be considered innocent only if they were not predisposed to commit the crime-those who had a prior intent to break the law were guilty and should be denied the defense. Entrapment's bearing on guilt made it a question for the jury, which could decide the issue of predisposition only after a searching inquiry into "the conduct and purposes of the defendant previous to the alleged offense." 18

14. See United States v. Russell, 411 U.S. 423, 439 (1973) (Stewart, J., dissenting).

15. See Murchison, The Entrapment Defense in Federal Courts: Emergence of a Legal Doetrine (pt. 1), 47 Miss. L. Rev. 211 (1976).

16. Almost all agree that the defense is necessary, but for a condemnation of the entire entrapment doctrine, see DeFeo, Entrapment as a Defense to Criminal Responsibility: Its History, Theory and Application, 1 U.S.F. L. REv. 243, 274 (1967).

17. 287 U.S. 435 (1932).

18. Id. at 451 . Hughes' argument that the defendant's act fell outside the sanctions of the 
Three subsequent Supreme Court cases have reaffirmed Hughes' subjective rationale, ${ }^{19}$ despite severe criticism from the commentators. ${ }^{20}$ The subjective approach focuses on the suspect's predisposition, which can be established not only by showing his willingness to commit the crime, but also with evidence of his reputation, prior crimimal record, and even rumors of past transgressions. ${ }^{21}$ Although some lower federal courts have treated certain kinds of governmental overinvolvement in the criminal enterprise as entrapment per se, ${ }^{22}$ the Supreme Court explicitly condemned this approach in United States $v$. Russell. ${ }^{23}$ Justice Rehnquist found the defendant's admitted predisposition to be "fatal to his claim of entrapment,"24 despite the agent's conduct in providing Russell with a scarce mgredient essential to the manufacture of inethamphetamine. Rehnquist found no constitutional grounds for the entrapment defense, though he did acknowledge that due process principles might absolutely bar prosecution if the agent's conduct was sufficiently outrageous. ${ }^{25}$ Hampton $v$. United States ${ }^{26}$ has now cast some

National Prohibition Act because Congress did not intend its laws to be enforced in an ignoble manner has been dismissed as a "strained and unwarranted construction of the statute," $i d$. at 456 (Roberts, J., concurring), and as "sheer fiction," Sherman v. United States, 356 U.S. 369, 379 (1958) (Frankfurter, J., concurring). Later entrapment opinions have not stressed legislative intent as a basis for the defense.

19. Hainpton v. United States, 425 U.S. 484 (1976); United States v. Russell, 411 U.S. 423 (1973); Sherman v. United States, 356 U.S. 369 (1958). For a thorough discussion of these later cases, including a convincing arguinent that they vastly expanded the scope of Sorrells without ever seriously reexamining its rationale, see Murchison, The Entrapment Defense in Federal Courts: Modern Developments (pt. 2), 47 Miss. L. REv. 573, 612-14 (1976).

20. See authorities cited in Rossum, The Entrapment Defense and the Supreme Court: On Defining the Limits of Political Responsibility, 7 MEM. ST. U.L. REv. 367, 386-87 (1977).

21. See United States v. Russell, 411 U.S. at 443 (Stewart, J., dissentimg); Sherman v. United States, 356 U.S. at 382 (Frankfurter, J., concurring); Murchison, supra note 19, at 606-08; Park, supra note 2, at 200-01.

22. These courts argued that the governinent's conduct per se barred the prosecution of the defendant without regard to that defendant's predisposition. See, e.g., United States v. McGrath, 468 F.2d 1027 (7th Cir. 1972), vacated mem., 412 U.S. 936 (1973), rev'd per curiam, 494 F.2d 562 (1974) (entrapment as a matter of law where agent acted as leader in establishing counterfeiting ring); Greene v. United States, 454 F.2d 783 (9th Cir. 1971) (no entrapment, but same underlying objections where agent supplied suspects with still, still site, equipment, and sugar); United States v. Bueno, 447 F.2d 903 (5th Cir. 1971), cert. denied, 411 U.S. 949 (1973) (same result where agent supplied suspect with heroin).

23. 411 U.S. 423 (1973).

24. Id. at 436.

25. Id. at $431-32$.

26. 425 U.S. 484 (1976). Justice Rehnquist held that due process was not violated when an agent provided the suspect, not simply with an imgredient of contraband, but with the contraband itself. Justice Rehnquist argued that Hampton "misapprehended" the due process language in Russell. Due process comes imto play only when a "protected right" of the defendant is violated, and Russell established that the governmental conduct in this case violated no constitutional rights. Id. at 490. Where the governinent agent and the defendant work together to commit a crime, defendant's remedy "lies solely in the defense of entrapment." Id. Hampton's predisposition rendered this defense unavailable to him after Russell, and his conviction was accordingly 
doubt on the viability of the due process argument.

The subjective approach of the Sorrells majority failed to persuade Justice Roberts, whose concurrence in that case introduced the rival objective or hypothetical person theory of entrapment. ${ }^{27}$ The objective theory examines the agent's conduct rather than the defendant's conscience; it views the entrapment defense as an essential means for the court to "preserve the purity of its own temple"28 by refusing to convict the victims of overly persuasive police tactics. The crucial question is not the defendant's guilt or innocence but "whether the police conduct revealed in the particular case falls below standards, to which common feelings respond, for the proper use of governmental power."29 These standards, which should be enforced regardless of the suspect's personal demerits, are determined by the "likelihood, objectively considered, that the police conduct would entrap only those ready and willing to commit the crime." ${ }^{30}$ The court decides the entrapment issue under this theory because it is responsible for the integrity of the judicial process which has been threatened. ${ }^{31}$

\section{B. California Cases}

The California Supreme Court's opinion in People v. Benford ${ }^{32}$ forced an unlikely reconciliation of the subjective and objective theories of entrapment. Benford espoused an objective rationale for the defense: a court inust recognize the defense "out of regard for its own digmity" when police conduct falls below proper standards, regardless of the accused's actual guilt or innocence. ${ }^{33}$ Benford also asserts, however, that the defense in California turns on "whether the imtent to commit the crime originated im the mind of the defendant or in the mimd of the entrapping officer . . .."34 This is simply a seinantic variation of the familiar subjective test, which focuses on the suspect's predisposition. California thus adopted an objective rationale with a subjective standard, ${ }^{35}$ a hybrid approach that has spawned an under-

affirmed. Rehnquist's due process argument did not persuade a majority of the Court, however, $i d$. at 492-93 (Powell, J., concurring), and the due process defense may still be available in particularly egregious cases of governmental participation in crime.

27. Sorrells v. United States, 287 U.S. at 459 (Roberts, J., concurring).

28. Id. at 457 (Roberts, J., concurring).

29. Sherman v. United States, 356 U.S. at 382 (Frankfurter, J., concurring).

30. Id. at 384 (Frankfurter, J., concurring).

31. United States v. Russell, 411 U.S. at 441 (Stewart, J., dissenting); Sherman v. United States, 356 U.S. at 385 (Frankfurter, J., concurring); Sorrells v. United States, 287 U.S. at 457 (Roberts, J., concurring).

32. 53 Cal. 2d 1, 345 P.2d 928 (1959).

33. Id. at 9, 345 P.2d at 933-34.

34. Id. at 10,345 P.2d at 934 .

35. The Benford court explained only that the origin of intent test is still restricted by the 
standably inconsistent series of entrapinent cases. ${ }^{36}$

In practice, California courts often observed vaguely that "public policy" (i.e., the objective concern with police standards) played a role in the defense, but they always apphed the subjective origin of intent test to the facts before thein. ${ }^{37}$ Courts applying that test seldoin overturned jury convictions, allowing juries to infer the defendant's preexisting intention to sell LSD, for example, from the facts that he had the drug in his possession and he sold it, despite evidence of extrenne coercion by the agent. ${ }^{38}$

One line of cases $^{39}$ did take seriously Benford's proposition that the defendant's guilt or innocence was immaterial to the question of entrapment in California. These cases interpreted this language, not as

rule in California against the use of prior convictions or evidence of police suspicion on the issue of entrapment. These types of evidence, allowed in the federal courts, were already prohibited in California even before Benford rejected the purely subjective approach. $I d$. at 11,345 P.2d at 935. Ironically, this bar only worked to Bcnford's disadvantage, as his clean record was given little weight. Id. at 12,345 P.2d at 936.

36. Compare, e.g., Patty v. Board of Medical Exauniners, 9 Cal. 3d 356, 508 P.2d 1121, 107 Cal. Rptr. 473 (1973) (although defendant rcadily complied with request for drugs, court could infer from clean background and unfamiliarity with vernacular that defendant had no preexisting intent) and People v. Goree, 240 Cal. App. 2d 304, 49 Cal. Rptr. 392 (2d Dist. 1966) (even "hair trigger susceptibility" does not negative entrapment as a mattcr of law) with Pcople v. Cordero, 240 Cal. App. 2d 826, 49 Cal. Rptr. 924 (4th Dist. 1966) (intent did not originate with female agent who flirted with defendant, discussed his interest in painting, agreed to pose for him, and finally succeeded in buying drugs from him on their sixth mceting) and People v. Hawkins, 210 Cal. App. 2d 669, 27 Cal. Rptr. 144 (1st Dist. 1962) (defendant had preexisting intent even though requests continued for six months before he succumbed).

37. See, e.g., Pcople v. Sweeney, 55 Cal. 2d 27, 357 P.2d 1049, 9 Cal. Rptr. 793 (1960). Justice Schauer, the author of Benford, concurred in Sweeney and so implied that Benford was not intended to be a rejection of the origin of intent test.

38. See People v. Moran, 1 Cal. 3d 755, 760, 463 P.2d 763, 765, 83 Cal. Rptr. 411, 413 (1970). In Moran, the agcnt approached thc eighteen year old suspect three times, appealed to his friendship, noted that he would sell the drug if their roles were reversed, and pleaded the cause of his friend who "needed the drug badly." Id. at 759, 463 P.2d at 764-65, 83 Cal. Rptr. at 412-13. See also Cordero, discussed at note 36 supra, in which the court found that the agent "merely made an opportunity available for defendant to commit the crime." 240 Cal. App. 2d at 828, 49 Cal. Rptr. at 926.

Chief Justice Traynor's dissent in Moran was one of the fcw pre-Barraza judicial acknowledgements of the confusion in California's entrapment doctrine. Traynor may have overstated Benford's commitinent to the objective approach, howevcr, in arguing that post-Benford decisions employing the origin of intent test "departcd froin the rationale of the Benford case and seriously undermincd the deterrent effect of the entrapment defense on imiperinissible pohice conduct." 1 Cal. 3d at 764-65, 463 P.2d at 768, 83 Cal. Rptr. at 416 (Traynor, C.J., dissenting). Although a footnote relied on by Traynor did state that the court was "primarily concerned with police conduct," it went on to suggest that the officer's belief that the suspect had "some knowledge of illicit drug trafic" created a presumption that the officer did not intend to entrap the suspect. People v. Benford, $53 \mathrm{Cal} .2 \mathrm{~d}$ at 13 n.5, 345 P.2d at 936 n.5. Objective entrapinent, of course, is concerned with police conduct and its effect on a lyypothetical suspect, not the policennan's state of mind.

39. See In re Foss, 10 Cal. 3d 910, 519 P.2d 1073, 112 Cal. Rptr. 649 (1974); People v. Moran, 1 Cal. 3d 755, 463 P.2d 763, 83 Cal. Rptr. 411 (1970); People v. Valvcrde, 246 Cal. App. 2d 318, 54 Cal. Rptr. 528 (5th Dist. 1966). 
a directive to focus attention on the police rather than on the suspect, but as a justification for relieving the government of its usual duty to prove guilt beyond a reasonable doubt. The federal courts typically required proof beyond a reasonable doubt of defendant's predisposition, ${ }^{40}$ but California courts applying a nearly identical test required the defendant to prove entrapinent by a preponderance of the evidence once any criminal intent was established. Benford's lofty policy arguinents thus acted only to the detriment of the defendant, who was denied the few benefits of the subjective theory by California's devotion to the hybrid approach. ${ }^{41}$

\section{III}

\section{ANALYSIS}

People v. Barraza's explicit rejection of the benighted hybrid approach to entrapinent should end much of the confusion engendered by Benford. Unfortunately, the supreine court fails once again to take a completely objective approach. It leaves the "normally law-abiding person" standard almost entirely undefined, even though this standard will tend to shift attention from the police to the suspect and will not reach all situations where the government inanufactures crime. An eniginatic footnote entrusts the entrapment issue to the jury rather than the court, in contrast to all prior objective formulations. Finally, the court will admit evidence of past transactions and difficulty of the crime's detection, evidence which should not influence an objective evaluation of the defense.

\section{A. Comparison of Approaches}

Since Barraza is predicated on the superiority of the objective approach, a full analysis of the opinion requires some coniparison of the opposing theories. Although much depends on one's outlook on the prosecution of victimless crimes, ${ }^{42}$ the two views of entrapinent can be

40. See United States v. Gardner, 516 F.2d 334, 348 (7th Cir. 1975), cert. denied, 423 U.S. 861 (1975); Notaro v. United States, 363 F.2d 169, 174-75 (9th Cir. 1966); Batson v. State, 568 P.2d 973, 976-78 (Alaska 1977); Murchison, supra note 28, at 604-06.

41. See note 35 supra for another instance of the defendant's dilemmas under the hybrid approach.

42. Many of the differences between the subjective and objective tests can probably be explained most easily as manifestations of divergent perspectives on law enforcement. As in the continuing debate over the exclusionary rule, the entrapment issue, when stripped of rhetoric, can be reduced to a simple question: If both the government and the citizen break the rules, whose misbehavior should be condoned and whose punished? Under the objective theory the defendant is excused because of the misconduct of the government, while the subjective theory grants the pohice a form of immaculate entrapinent as long as they choose the correct suspects to entrap. 
compared by appraising the legitimacy of their purposes and their relative performance in attaming their goals.

Both theories seek to prevent the government from manufacturing crime or seducing innocent people into becoming criminals, ${ }^{43}$ but each view emphasizes different concerns. The objective theory focuses on the governmental involvement because its purpose is to prevent police inisconduct and preserve the integrity of the judicial process. The subjcctive theory, particularly in its recent manifestations, is not as concerned with the police misconduct as it is with the prospect of "guilty" people going free while innocent people go to prison. Its adherents claim that only nonpredisposed suspects deserve the entrapment defense, and that only the subjective theory adequately protects them. ${ }^{44}$ They charge that traditional objective formulations would not only prosecute some of these people, but would simultaneously protect such obviously predisposed suspects as the defendant in United States v. Russell $^{45}$ The subjective test would protect innocent people who succumb to only mild persuasion, while convicting predisposed criminals even if the agent may have used persuasive tactics.

The flaw in the subjective rationale is that it presupposes an independent means of determining the suspect's guilt or innocence. A predisposed suspect is a guilty suspect, but unless the predisposition is admitted, it is impossible to prove that a particular suspect was ready and willing to commit the crime if the only evidence agamst him is his response to highly persuasive police tactics.

The subjective theory solves this conundrum by allowing the government to prove "predisposition" with evidence of the defendant's criminal record, reputation, and character, although such evidence has no bearing on his readiness to commit an offense in this instance unless it is assumed that prior offenders are always ready to commit another crime. ${ }^{46}$ The test does not protect all nonpredisposed people, but only those with a clean record or decent reputation, and it may protect suspects with these attributes even though they were ready to commit the crime in question. Guilt or innocence is determined on the basis of questionable inferences from hearsay evidence. ${ }^{47}$ The subjective the-

43. See United States v. Russell, 411 U.S. at 439 (Stewart, J., dissenting).

44. See Park, supra note 1, at 217-21.

45. 411 U.S. 423 (1973). Russell manufactured drugs before the agent approached him, and admitted his predisposition.

46. In attenpting to establish this type of "predisposition," the government can introduce hearsay evidence of rumors or suspicions concerning the defendant. A jury inight well consider this evidence, despite a contrary instruction, in determining the defendant's guilt in the charged offense. Good discussions of the problems associated with this evidence can be found in United States v. Russell, 411 U.S. at 443 (Stewart, J., dissenting); Sherman v. United States, 356 U.S. at 382 (Frankfurter, J., concurring); Park, supra note 2, at 200-01.

47. Even those defendants with unblemished reputations and no prior criminal record are 
ory therefore promotes the imterests of justice too feebly to justify its countenance of overzealous police conduct.

California's origin of intent test shared a common problem with federal subjective theory-there was no way to establish that intent originated in the defendant's mind when he committed the crime only after encountering unduly persuasive police conduct. The proof problem was shifted to the defendant, however, who had to establish by a preponderance of the evidence that he did not origmally intend to commit the crime. Juries have been allowed to infer intent from evidence that demonstrated little more than that the crime was committed and the defendant was able to commit it. ${ }^{48}$ People $v$. Benford's attempt to ameliorate the subjective test's problems by combining it with the public policy of controlling police conduct was doomed to failure because the two theories are logically irreconcilable, and the public policy rationale did nothing to shift the burden from the defendant.

The objective approach avoids these evidentiary problems and provides a more consistent rationale for the entrapment defense. There is no need to introduce prejudicial evidence in an attempt to show predisposition because the objective test seeks, like the exclusionary rule, to deter improper police methods without regard to the individual defendant's guilt or innocence. The defendant goes free because the government has abused its power and fallen below acceptable standards for law enforcement. Suspects are not treated differently depending upon their history. ${ }^{49}$ All cases are decided on the basis of the propriety of the agent's conduct.

The main problem under the objective approach is deciding what constitutes acceptable police conduct. Prior formulations have been regrettably vague, speaking in terms of "standards, to which common feelings respond, for the proper use of governmental power." ${ }^{\text {" }}$ Many attempts liave been made to add substance to these standards, usually by positmg a hypothetical person who is not ready and willing to commit the crime, and then determining whether the undercover methods employed would tempt such a person. Critics claim that the police conduct is still viewed in a vacuum, but it is difficult to be more specific.

not actually "innocent," as the subjective theorists imply, because they have in this instance committed precisely the crime with which they are charged. Sherman v. United States, 356 U.S. at 379 (Frankfurter, J, concurring). If they were innocent, then it should not matter whether a police officer or a private person induced the behavior, yet entrapment protects only those induced by the pohce. United States v. Russell, 411 U.S. at 442 (Stewart, J., dissenting).

48. See, e.g., People v. Moran, 1 Cal. 3d 755, 463 P.2d 763, 83 Cal. Rptr. 411 (1970); People v. Cordero, 240 Cal. App. 2d 826, 49 Cal. Rptr. 924 (4th Dist. 1966). See also DeFeo, supra note 16 , at 267.

49. See note 47 supra.

50. Sherman v. United States, 356 U.S. at 382 (Frankfurter, J., concurring). 
An "average person" standard will not work because an average person would probably not commit a serious crime unless subjected to some sort of duress, and police tactics may be objectionable even when they do not amount to duress. ${ }^{51}$ If the standard is given meaning by per se rules against specific police approaches, such rules will tend to trap the innocent or unsophisticated while shielding the labitual crimmal, who may simply require each custouner to overstep the rules before doing business witlı him. ${ }^{52}$

These practical problems witl the objective test may partially explain its limited success in the courts. Any court that adopts the objective position inust make it work in practice without sacrificing too many objective tenets. The Barraza opinion is only partially successful in this task.

\section{B. Barraza's Standard and Guidelines}

Prior formulations of the objective test have usually postulated a hypothetical person who was not "ready and willing to commit the crime" before being approached by the police. ${ }^{53}$ Without such a provision the test would truly be judging police conduct im a vacuum-some mention unust be made of the type of person who would respond to the persuasive tactics, in order to determine whether those tactics violate standards for the proper use of governmental power. This process inevitably shifts soine attention toward the suspect, but the primary focus remains on the police conduct, which is judged by its probable effect on the hypothetical suspect.

Although Mosk presumably intended the "nornally law-abiding person" standard to serve a sinilar function, Barraza reverses the usual inquiry by making the standard the cornerstone of the opinion. Every step in the new doctrime is preinised on the "normally law-abiding person" and makes explicit reference to that concept. Attention is focused on this lypothetical person and, by comparison, upon the suspect himself.

Unfortunately, despite the constant focus on the "normally lawabiding person," the concept remains largely undefined. Justice Mosk's only clarification is that such a person would resist temptation when "presented by the simple opportunity to act unlawfully."54 This alone

51. See Pascu v. State, 577 P.2d 1064, 1066-67 (Alaska 1978); Park, supra note 1, at 172-74.

52. See Rossum, supra note 20 , at $392-93$.

53. See, e.g., Sherman v. United States, 356 U.S. at 384 (Frankfurter, J., concurring); People v. Moran, 1 Cal. 3d at 765, 463 P.2d at 769, 83 Cal. Rptr. at 417 (Traynor, C.J., disscnting); Grossman v. State, 457 P.2d 226, 229 (Alaska 1969); Model Penal Code § 2.13(1)(b).

54. $23 \mathrm{Cal}$. 3d at $690,591 \mathrm{P} .2 \mathrm{~d}$ at $955,153 \mathrm{Cal}$. Rptr. at 467. The actual wording for the test is apparently derived from the Brown Commission report, discussed in Park, supra note 1, at 16869 n.16, 173 n.28. 23 Cal. $3 d$ at 389 n.3, 591 P.2d at 955 n.3, 153 Cal. Rptr. at 467 n.3. 
provides little illumination, but Justice Mosk does explain that the police do more than simply provide an opportunity when they engage in "overbearing conduct such as badgering, cajoling [or] importuning." 55 Even this explanation is circular-the conduct must still be "likely to induce a normally law-abiding person to commit the offense."56 A fuller definition is still needed, as shown by the facts of Barraza. Although the agent's harrassment of Barraza was overbearing conduct, it is questionable whether it would have induced a norunally law-abiding person to write a note introducing the agent to a heroin pusher. The "normally law-abiding person" might have no criminal background and might not even know anyone engaged in illicit pursuits. Conceivably, the normally law-abiding person could be one who only follows the rules "generally," or who knows underworld characters but does not lead a criminal life himself. 57

Any attempt by courts or juries to give ineaning to the standard will add an unnecessary step to the determination that inust be made, and will tend to obscure what the police have been doing by focusing on the suspect rather than on the conduct. Prosecutors in cases such as Barraza will be able to capitalize on the vagaries of the standard by asking the jury whether they, as normally law-abiding people, would ever sell dangerous drugs. Assuming that the general public has no access to the drugs and that any juror remotely linked with a drug offense will have been eliminated by peremptory challenge, the jury's response is not difficult to predict. A normally law-abiding person would not introduce the agent to a heroin dealer, but would simply call the police to end the harassment. Yet the police pressure might well elicit a reference to a drug dealer from a person who normally obeys the law but is acquamted with those who do not, and so manufacture crime. This sort of suspect, of which Barraza seems an example, could be included in the meaning of a "normally law-abiding person," but it may be difficult to lead a jury to believe that.

The Barraza standard creates another danger not posed by most prior formulations of the objective approach. Any test predicated on the "normal" or "average" person (as opposed to someone "not ready to commit the crime") runs the risk of emasculating the entrapment defense, because most people will not commit a serious crime unless subjected to extreme pressure or duress. Barraza is likely to narrow the scope of the defense still further: the term "normally law-abiding person" has connotations of moral rectitude absent froln the notion of the

55. Id.

56. Id.

57. See 23 Cal. 3d at 693, 591 P.2d at 957, 153 Cal. Rptr. at 469 (Richardson, J., dissenting on entrapment issue). 
"average person." Only threats or some outrageously attractive proposition would cause such a person to commit a felony, and many subtler forms of entrapment would escape condemnation. The test would almost certamly not reach the conduct in Russell, because even providing the nonnally law-abiding person with a scarce, essential ingredient would not tempt that person to begin manufacturing drugs. Barraza will therefore not reach conduct traditionally condemned under the objective theory.

Justice Mosk may not have intended Barraza to cover the Russell situation, ${ }^{58}$ which does present the objective theory with its most difficult case. Providing suspects with an essential ingredient for drug manufacture will probably not attract any "normal" people, and it might be argued that such police activities are not so offensive that they justify releasing someone who had been engaged in committing precisely the crime of which he is accused. Although objective entrapment opinions have not countered this argunent very effectively, ${ }^{59}$ these police activities are offensive because they are likely to manufacture crime. The entrapment defense is not designed to protect Russell, but police techniques employed to deceive such a person miglit also induce others, not previously engaged in crime, to enter an illicit busmess once the agent makes crime so easy and attractive. The induceinent might not attract an average law-abiding person. It might well attract a segment of society whose inembers cannot be classified as either saints or smners, whose moral reservations may not be very strong, but who are not ready and willing to commit a crime. They would be tempted to do so only by a particularly attractive proposition. Barraza will not protect these people, and will allow the police to entrap those who might never have committed a crime but for the conduct of the police. ${ }^{60}$

The problems with the "normally law-abiding person" standard are somewhat ameliorated by Mosk's two general guidance principles

58. There is no way to ascertain Justice Mosk's view of the Russel/ and Hampton situations-he cites Russell only in passing and ignores Hampron entirely. 23 Cal. 3d at 687, 591 P.2d at 954,153 Cal. Rptr. at 466.

59. Many lower federal courts simply argued that governmental overinvolvement in crime made it likely that crime would arise through the creative activity of the government. They developed per se rules against such involvement, without explaining how the police were manufacturing crime if the inducements would only tempt someone already engaged in committing the crime. See text accompanying note 22 supra. Justice Stewart's dissent in Russell seemed to argue that, although the defendants were committing other crimes, there was entrapment because they would not have committed the crime charged but for the creative activity of the government. 411 U.S. at 448-49 (Stewart, J., dissenting). This argument, however, could be made in any case where a suspect is solicited by an agent, because the particular criminal transaction charged would never have been committed if the agent had not approached the suspect.

60. See notes 77-82 and accompanying text infra. Such people as Hampton, Cordero, and Moran, discussed supra at notes 26,36 , and 38 respectively, as well as Barraza, would probably be members of this seginent of society. 
which, though still couched in terms of the standard, tend to refocus attention on the police conduct. The first principle prohibits the police from generating a motive "other than ordinary criminal intent," e.g., an appeal to sympathy or friendship. ${ }^{61}$ An appeal to noncriminal motivations is easily recognizable as such and might impel even a normally law-abiding person to commit a crime. This principle is a welcome judieial statement that the pohice do not benefit society when they induce crime by preying on a suspect's altruistie tendencies.

Mosk's second principle is more closely tied with the "nornally law-abiding person" standard. The police cannot make the crime "unusually attractive" by, for example, offering exorbitant consideration or by guaranteemg that the act is legal or undetectable. ${ }^{62}$ While these are not noncriminal mcentives, they can still manufacture crime by naking a criminal enterprise irresistible to someone who might never otherwise have committed an offense. This prineiple would presumably cover the Russell situation if not for the "normally law-abiding person" standard, which renders the rest of the principle somewhat ineffectual. Conduct which might make erime attractive to someone who had previously managed to keep his faint criminal tendencies within check may have no effect on the "normally law-abiding person," if the jury views that as an average person. The principle will probably do little to obviate the risks that the police will manufacture crime by making it unusually attractive to those who were not ready and willing to commit an offense. ${ }^{63}$

\section{Entrapment as a Jury Question}

The subjective theory regards an entrapped person as innocent, and leaves the question with the jury as part of its determination that the defendant is guilty beyond a reasonable doubt. Under the objective theory the defendant's guilt or innocence is irrelevant. The court decides the issue as arbiter of the standards of justice which have been threatened by the possibly overzealous police conduct. ${ }^{64}$ In a cryptic footnote, however, Barraza relegates its objective test to jury determination, ostensibly because entrapment has a "potentially substantial effect on the issue of guilt." ${ }^{\prime \prime 5}$ This is roughly comparable to a footnote in

61. 23 Cal. 3d at 690,591 P.2d at 955,153 Cal. Rptr. at 467.

62. Id.

63. The "unusually attractive" guideline is further weakened by dicta that the police must "remain free to take reasonable, though restramed, steps to gain the confidence of suspects" in order to set them up for arrest. Id. at $690 \mathrm{n} .4,591$ P.2d at 955 n.4, 153 Cal. Rptr. at 467 n.4.

64. See United States v. Russell, 411 U.S. at 441 (Stewart, J., dissenting); Sherman v. United States, 356 U.S. 385 (Frankfurter, J., concurring); Sorrells v. United States, 287 U.S. at 457 (Roberts, J., concurring).

65. 23 Cal. 3d at 691 n.6, 591 P.2d at 956 n.6, 153 Cal. Rptr. at 468 n.6. 
Miranda v. Arizona ${ }^{66}$ explaining that, although custodial interrogations are inherently coercive, confessions obtained during these interrogations are admissible even in the absence of procedural safeguards because any such statements by the defendant are potentially indicative of guilt.

There may be valid reasons to leave entrapinent with the jury even if it has no bearmg on guilt. ${ }^{67}$ It night be argued, for example, that the "normally law-abiding person" should be decided on the basis of general coininunity standards, a cominon jury determmation, or that the jury should decide the issue so that it can provide a lay person's check on overzealous governmental prosecution of crime. ${ }^{68}$ Unfortunately, the primary question under the objective test is the conduct of the police, not that of the hypothetical suspect, and juries are relatively unaware of the practices and problems of law enforcement. The test lends itself to jury determination only msofar as it retreats from the objective viewpoint, and community standards will not help to determine the reasonableness of police conduct. Juries have also served as relatively ineffective checks on the government in this area, either as a result of the vague test which they have been asked to apply or because of their unwillingness to free a lawbreaker for the sake of preventing future irregularities in police work. ${ }^{69}$

The main problems created by leaving the question to the jury are those recognized years ago by Chief Justice Traynor. ${ }^{70}$ A jury verdict either way tells the police nothing: a guilty verdict may mean only that the jury did not believe the defendant's entrapment testimony, and a verdict of not guilty may be founded on a belief that the defendant did

66. 384 U.S. 436 (1966).

67. Justice Mosk may have provided no better explanation because he did not believe there was one. As he makes clear, Justice Mosk, along with Justices Tobriner and Newman, thought that the trial court should decide the entrapment issue. Id. Unfortunately, neither Chief Justice Bird nor Justice Manuel, the two members of the majority who strayed from the objective tradition on this point, wrote concurring opinions to justify this deviation from prior formulations of objective entrapment. Justice Mosk not only recognized the imcongruity of objective entrapment as a jury question elsewhere in the opinion, $23 \mathrm{Cal} .3 \mathrm{~d}$ at 686-87, $591 \mathrm{P.2d}$ at 952-53, $153 \mathrm{Cal}$. Rptr. at 464-65, but he also jomed in the Moran opinion, requiring a defendant to prove entrapment by a preponderance of the evidence, precisely because entrapment has no bearing on guilt. 1 Cal. 3d at 760, 463 P.2d at 765, 83 Cal. Rptr. at 413.

68. A right to jury trial is granted to criminal defendants in order to prevent oppression by the Government. . . . The framers of the constitution strove to create an independent judiciary but insisted upon further protection against arbitrary action. Providing an accused with the right to be tried by a jury of his peers gave him an inestiunable safeguard against the corrupt or overzealous prosecutor and against the compliant, biased, or eccentric judge.

Duncan v. Louisiana, 391 U.S. 145, 155-56 (1968).

69. See Park, supra note 1 , at 267 n.337.

70. See People v. Moran, 1 Cal. 3d at 766, 463 P.2d at 769, 83 Cal. Rptr. at 417 (Traynor, C.J., dissenting). 
not commit the crime. Even if the entrapment question is explicitly decided, a jury verdict cannot give the police standards that would result from a line of court-decided cases.

If the question were reserved to the court, speculation as to the reasoning behind the jury's decision would end and the courts could develop explicit standards on permissible police conduct, something which jury verdicts will not do. In light of their frequent exposure to police activity, the courts should also be better equipped to judge that activity, and less likely to ignore overly enthusiastic law enforcement. The entrapment question should be reserved to the court, as it has been under all previous objective schemes.

\section{Evidence}

Subjective considerations also intrude on Mosk's discussion of the evidence that the jury should consider in applying the new test. Mosk observes that police conduct should be "judged by the effect it would have on a normally law-abiding person situated in the circumstances of the case at hand."71 While some evidence of surronnding circumstances is necessary to view the police conduct in context, other evidence may bear prejudicial information about the suspect's predisposition. Barraza admits both types of evidence.

The suspect's responses to the officer and the gravity of the crime are relevant in determining whether the suspect was entrapped. ${ }^{72}$ Most people would be more easily persuaded to joim an illegal poker game than to smuggle large amounts of cocaine into the country from Peru, so there is a greater chance that the police are manufacturmg relatively minor offenses. ${ }^{73}$ A suspect's responses to the inducement must be admitted to perinit a full evaluation of the pressure applied by the agent, and to assure that the suspect is not smiply a street-wise veteran playing along until he hears the magic phrases of entrapment.

The court would also allow evidence of past transactions witl the suspect and of the difficulty of detecting the crime cliarged. ${ }^{74}$ Past transactions are traditionally used to suggest predisposition, an irrelevant concern in an objective test. ${ }^{75}$ The police could imply a freedom

71. 23 Cal. $3 d$ at 690,591 P.2d at 955,153 Cal. Rptr. at $467-68$.

72. Id.

73. This is a corollary to the argumeut that an average person would commit a serious crime only if coerced. If gravity of the crime is a criterion and "normally law-abiding person" is the standard, any defendant charged with a very serious offense will probably be effectively denied the entrapment defense. See text accompanying note 51 supra.

74. 23 Cal. 3d at 690, 591 P.2d at 955, 153 Cal. Rptr. at 467-68.

75. Any negotiations leading up to the sale for which the suspect is on trial must be admitted to get an accurate picture of the circumstances of that crime. "Past transaetions," however, presumably includes evidence of prior sales and dealings with the police which may be entirely unre- 
to tailor their approach to bring more pressure to bear on persons with whom they have had previous contact, but objective doctrine seeks to set generalized limits on police tactics. The jury may be unduly influenced by prejudicial testimony of unprosecuted past crimes, which could be "proven" only in a swearing match between police and defendant.

The difficulty of detecting a crime, though a justification for initiatimg some sort of undercover police operations, does not justify the result of those operations if they tend to manufacture crime. ${ }^{76}$ Induceinents that would be likely to manufacture obvious crimes are just as likely to manufacture secretive offenses. The police may have more reason to work undercover in certam cases, but they should still be required to adhere to acceptable standards of undercover work regardless of the type of case.

\section{IV}

\section{An Objective Alternative}

Although Barraza proposes a lamentably flawed version of the objective approach to entrapment, a truly objective test can be devised that would hold more promise of both theoretical and practical consistency. The primary focus should be on a concern cominon to both theories of entrapment: the likelihood that the conduct of the law enforcement agent would manufacture crime. Alaska, which pioneered the objective test im state courts, ${ }^{77}$ recently adopted a variation of this approacli after discarding its old "average person" standard as unworkable. In Pascu v. State, ${ }^{78}$ the Alaska Supreme Court explamed that entrapment should prohibit "unreasonable or unconscionable efforts on the part of the police to mduce one to commit a crime so that he may be arrested and prosecuted for the offense."79 In other words, as the Alaska court makes clear elsewhere in the opinion, ${ }^{80}$ the entrapment defense should deter the state from manufacturing crime.

A comprehensive entrapment test must include the agent's conduct

lated to the present charge. Such evidence should be inadmissible under the objective theory as irrelevant to the police conduct in question.

76. It may be that Justice Mosk intends to require that the governınent show difficulty of detection before it can use entrapping techniques. Such a showing has not been required before, lowever, and from the placement of this factor among the circumstances relevant in judging the police conduct it seems nore likely that this evidence will be used to justify the use of especially persuasive or uuusual tactics, rather than as a prerequisite for any undercover work.

77. Grossinan v. State, 457 P.2d 226 (Alaska 1969).

78. 577 P.2d 1064 (Alaska 1978). Although the case is not cited in Barraza, it is quoted in a later California Supreine Court entrapment decision, People v. McIntire, 23 Cal. 3d 742, 745, 591 P.2d 527, 528-29, 153 Cal. Rptr. 237, 239 (1979).

79. 577 P.2d at 1067 .

80. Id. at 1068 u.I1. 
in Russell. The police can manufacture crime even if their conduct would not teinpt an average or "normally law-abiding person" to commit the crime. As argued above, ${ }^{81}$ the defendant should have an entrapment defense where police conduct is of a type that would induce those who, although not impeccable, would not have committed the crime unless confronted with unduly persuasive tactics. Altlough Russell himself would have made drugs with or without the government's help, the agent's offer to provide the one essential, scarce ingredient and to buy all the illicit drugs that the suspect could produce would also tempt some people who would never otherwise manufacture narcotics.

Once the court defined the focus as the manufacture of crime and identified the hypothetical person as one not ready to commit the crime, it should add, not per se rules, but guideline considerations. One of these should be whether the police created a motive other than ordinary criminal intent by appealing to sympathy or friendship, or by pressurimg or threatening the suspect to act out of fear or a desire to escape extraordimary harassment. Justice Mosk's second principlewhether the pohce have made the crime unusually attractive-could also be employed, once it was clear that the crime need not be especially attractive to the normally law-abiding person. ${ }^{82}$ Any offer that would make the crime exceptionally easy to commit should be condemned. These guidelines are exemplary, not per se rules, and should not be susceptible of abuse by professional criminals, who cannot demand unusual motives, rare substances, or exorbitant prices from every potential customer.

Under this proposal, only evidence of the agent's approach and the suspect's response in this particular transaction is admissible to estabhish the circumstances of the case. Despite these limitations, police conduct is not viewed in a vacuum: the transaction is analyzed on its facts, and there is no need to introduce prejudicial evidence of prior dealings to determine the propriety of the police conduct in this imstance. Finally, while it may be appropriate for the defendant to carry the burden of proving this affirmative defense, the question should be decided by the court out of the presence of the jury. The court can best articulate and enforce restrictions on police conduct without considerimg the defendant's personal demerits.

81. See text accompanying notes 58-60 supra.

82. Thus, in Barraza, the trier of fact could find that the agent's persistent and embarassing contacts at Barraza's office could goad a person familiar with drug peddlers (though not one himself) into aiding the agent in obtaining narcotics. If this is a likely result, then it suggests that the pohice could manufacture crime that would not otherwise have occurred by the use of these tactics. 


\section{CONCLUSION}

The supreme court correctly views the objective approach to entrapment as the best means of preventing the police from manufacturing crime, but im People v. Barraza it has propounded an unsatisfactory version of that approach. The court has predicated its doctrine upon an amorphous "norinally law-abiding person" standard which will misfocus attention on the suspect and may narrow the defense drastically. The suggested guidelines are potentially useful to an objective test but are compromised in Barraza by the standard. Finally, the court leaves the control of police conduct to juries unfamiliar witl law enforcement problems and faced with an admittedly guilty defendant, and then allows that jury to consider evidence suggestive of the defendant's predisposition. Although the Barraza decision is a theoretical improvement on the inherently contradictory "hybrid approach" which it supplants, its vagaries do not bode well for the future coherence of entrapinent doctrine in California.

Paul Kleven*

People v. McIntire. ${ }^{1}$ The court extended the entrapment defense to suspects entrapped by "unwitting agents" of the government. The defense had previously been unavailable to defendants entrapped by a private citizen unless that citizen was an inforınant knowingly aiding police. ${ }^{2}$ The McIntire court held that "unsuspecting dupes" manipulated by police into entrapping suspects could be considered government agents for entrapment purposes.

McIntire involved a narcotics investigation at a Los Angeles area high school. An undercover police officer testified that he had heard froin a student, Scott, that defendant, Gail McIntire, was selling marijuana. On October 15, 1976, the officer met defendant's younger brother, Todd, and later that day received marijuana from the defendant and saw her accept payment from Scott. Todd and Scott claimed they had said nothing to the officer regarding defendant's alleged narcotics dealings. According to them, the officer had met Todd seven

* A.B. 1977, University of California, Berkeley; J.D. 1980, Boalt Hall School of Law, University of California, Berkeley.

1. 23 Cal. 3d 742, 591 P.2d 527, 153 Cal. Rptr. 237 (1979) (Mosk, J.) (unanimous decision).

2. See United States v. Russell, 411 U.S. 423, 442 (1973) (Stewart, J., dissenting); see also Park, The Entrapment Controversy, 60 MinN. L. REv. 163, 171 n.21 (1976). 
weeks before the sale, and during that time had pressured him incessantly for marijuana. Todd charged that the officer continued to urge him to ask his sister for marijuana even after she had indicated she had neither drugs nor access to them. The defendant testified she had never before sold drugs, and had only obtained marijuana for Todd because he had asked her daily to find some. McIntire said that she wanted to help him because of his difficulties getting along with their mother and step-father. Despite this testimony, the trial court refused to instruct on entrapment.

At the outset, the court noted People v. Barraza ${ }^{3}$ was applicable only to trials begun after that decision became final; ${ }^{4}$ consequently, the case would be decided under the now discarded subjective theory of entrapment. ${ }^{5}$ The court noted substantial evidence in the record froin which a jury could have reasonably found the pre-Barraza elements of entrapment-lack of criminal predisposition and improper government inducement of crime. The defense testimony supported a conclusion that the defendant was not involved in drug traffic and did not want to supply the marijuana. She had done so only after considerable badgering by her younger brother and out of sympathy for his family problems. This urging, the jury could have concluded, directly resulted from the undercover officer's constant pressure on the brother. The agent's manipulation of the brother may well have been "precisely the sort of improper fostering of crime the entrapment defense is intended to prevent." $" 6$

The supreme court criticized the trial court's refusal to give an entrapment instruction as leadimg to an "irrational and dysfunctional result." The police should not be allowed to entrap suspects with impunity simply by reaching them indirectly through unknowing agents. Such agents, the court felt, are as much the tools of the police as those aware of their role and function as police agents.

Entrapment theory, whether objective or subjective in approach, does not reach one private individual's investigation of another's criminal conduct; it is designed to prevent only the governmental manufacture of crime. However, this fundamental tenet has misled soine courts to conclude that there can be no entrapment where a knowing govern-

3. 23 Cal. 3d 675, 591 P.2d 947, 153 Cal. Rptr. 459 (1979). For a discussion of the Barraza case, see Note, 68 CALIF. L. Rev. 746 (1980).

4. 23 Cal. 3d at 691 n.5, 591 P.2d at 956 n.5, 153 Cal. Rptr. at 468 n.5.

5. For a description of the subjective theory of entrapment used by California courts prior to Barraza, see generally Note, supra note 3, 751-53.

6. 23 Cal. $3 \mathrm{~d}$ at 747,591 P.2d at 530,153 Cal. Rptr. at 240. Although the court here ostensibly applied a subjective test, its phraseology is more suggestive of the objective approach. See, e.g., United States v. Russell, 411 U.S. 423, 447, 449 (1973) (Stewart, J., dissenting).

7. 23 Cal. $3 d$ at 748,591 P.2d at 530, 153 Cal. Rptr. at 240. 
ment agent did not directly contact the suspect. ${ }^{8}$ As $M c$ Intire makes clear, the government may remain the imstigator of criminal behavior even though the contact is indirect and through an unwitting suspect.

Unfortunately, the extreme factual setting of the case and the transitional nature of the opinion makes it difficult to draw firm conclusions about the scope of McIntire. One unresolved issue is whether the unwitting intermediary must also use entrapping tactics on the suspect. For example, would McIntire be entitled to assert the entrapment defense if her brother had asked her for the drugs only once? Under the subjective theory, a jury probably would find that she was predisposed to commit the crime and deny the defense. On the other hand, the objective theory only examines the official's conduct; if the official acted improperly, the defense would be successful regardless of the intermediary's conduct. Justice Mosk seems to have adopted the objective approach by focusing on police conduct and by failing to set standards of entrapping conduct for the intermediary.

Hawkins v. Superior Court. ${ }^{1}$ The court held that indicted defendants are entitled to a postindictment prelimmary hearing. The Cahfornia Constitution's equal protection clause guarantees indicted defendants the procedural right of a preliminary liearing, previously available only to those charged by information.

The grand jury's indictment charged the defendants with conspiracy and grand theft. At arraignment, they pleaded not guilty. Alternative motions for dismissal or a postindictment prelimmary hearing were denied. The defendants then sought a writ of mandate from the supreme court, claiming that the due process and equal protection clauses of the federal and state constitutions entitled them to an adversarial preliminary hearing. The supreme court, relying solely ${ }^{2}$ on the equal protection clause of the state constitution, held that an indicted defendant is entitled to a postimdictment preliminary hearing. The court directed the prosecutor to refile the indictment as a complaint. ${ }^{3}$

8. See United States v. Dodson, 481 F.2d 656, 658 n.3 (5th Cir. 1973); United States v. Gonzales, 461 F.2d 1000, 1001 (9th Cir. 1972); Carbajal-Portillo v. United States, 396 F.2d 944 (9th Cir. 1968).

1. 22 Cal. 3d 584, 586 P.2d 916, 150 Cal. Rptr. 435 (1978) (Mosk, J.) (5-2 decision).

2. Id. at $586-87,586$ P.2d at $917,150 \mathrm{Cal}$. Rptr. at 436 . The court did not address the "serious due process issue." $I d$.

3. Id. at 594,586 P.2d at 922,150 Cal. Rptr. at 441 . 
The court ${ }^{4}$ first noted the disparity between the procedural rights accorded an indicted defendant and one charged by information. The latter receives a preliminary hearing, which includes many procedural protections, such as representation by counsel, a hearmg before a neutral and trained magistrate, an opportunity to cross-examine witnesses, and the opportunity to appear personally and present exculpatory evidence. A person charged by indictment receives none of these protections. $^{5}$

The court found that the procedural rights available at a preliminary hearing, particularly the right to counsel, are fundamental. ${ }^{6}$ Applying traditional equal protection analysis, the court concluded that the state cannot deprive an individual of fundamental rights unless it has a compelling interest in doing so, and the discriminatory classification of individuals is necessary to promote that interest. Tactical reasons $^{7}$ a prosecutor may have for proceeding by indictment instead of information do not constitute a compelling state interest.

The dissent disagreed with the majority on two grounds. First, it cited constitutional reform comments which consistently demonstrate that the wording of the constitution's felony prosecution section had been kept deliberately broad, to allow the legislature latitude in developing specific rules and reforms regarding grand jury operation. The

4. Justices Tobriner, Manuel, and Newman joined Justice Mosk in the opinion of the court. Chief Justice Bird concurred separately, and Justices Richardson and Clark dissented. In addition, Mosk wrote a separate concurrence, joined by Newman, to espouse the view that the court should add a third, internediate level of scrutiny to traditional two-tier equal protection analysis. Chief Justice Bird wrote her concurrence solely to rebut that argument.

5. 22 Cal. 3d at 587, 586 P.2d at 917-18, 150 Cal. Rptr. at 436-37. See Cal. Penal Code $\$ \S 859-866.5$ (West 1970) (procedure when defendant charged by inforination).

6. $22 \mathrm{Cal} .3 \mathrm{~d}$ at $592-93,586 \mathrm{P} .2 \mathrm{~d}$ at $921,150 \mathrm{Cal}$. Rptr. at 440 (quoting Johnson v. Superior Court, 15 Cal. 3d 248, 266, 539 P.2d 792, 804, 124 Cal. Rptr. 32, 44 (1975) (Mosk, J., concurring)). While the court did not explicitly base its holding on the absence of counsel, the major procedural deprivations suffered by an indicted defendant all relate to the lack of participation by counsel in the grand jury room. Furthermore, the court relied heavily on the reasoning of Coleinan v. Alabama, 399 U.S. 1 (1970), which held that the assistance of counsel at a preliminary hearing is a fundamental right.

7. In his concurrence, Mosk collects most of the reasons advanced by prosecutors for proceeding by indictment:

indictment procedures (1) save tinue; (2) protect witnesses against embarrassing crossexamination; (3) protect an innocent accused when no indictment is returned; (4) protect the cover of an informant; (5) protect witnesses agamst harm or intimidation; (6) allow the prosecuting attorney to test his case and obtain a community viewpoint on its strength; (7) permit the evidentiary learing to be held over an extended period of tine; (8) facilitate investigations, e.g., by providing subpoena availability without the mitiation of formal proceedings; (9) allow the prosecutor to toll the statute of limitations when the defendant is absent (Pen. Code, $\$ \S 800,803)$; (10) protect the defendant from prejudicial pretrial publicity; (11) protect society from the flight of the accused; and (12) permit the prosecuting attoruey to share responsibility for the prosecution with the grand jury when there is great public interest in a case.

22 Cal. 3d at 604, 586 P.2d at 929, 150 Cal. Rptr. at 448. 
dissent further argued that the constitutional power to alter the grand jury system rests with the legislature alone, and concluded that the court's "tacking on" of a new procedure altering the grand jury system was beyond the scope of the court's constitutional authority. ${ }^{8}$ Second, the dissent argued that any differences in the functioning of the two felony prosecution tracks were not sufficient to deprive an indicted defendant of equal protection of the law. ${ }^{9}$

While the court's holding is novcl, ${ }^{10}$ the reasoning is sound and the decision is commendable for its recognition of the reahities of grand jury operations today. The court realized that the prosecutor's complete control of the grand jury, and the accused's effective deprivation of counsel, amount to a violation of rights properly considered fundamental.

In quantitative terms, Hawkins will have only a minor impact on prosecutorial behavior. Before Hawkins, less than five percent of crintinal prosecutions in Califorma were initiated by imdictment. ${ }^{11}$ This figure will become even smaller in the future. ${ }^{12}$ Hawkins will not affect the vast majority of felony prosecutions--those initiated by information.

The legislature should adopt the Hawkins rule as the first step in a wider reform of the grand jury system. ${ }^{13}$ The legislature should provide for empaneling two grand juries im each county, one to handle the indictment function and the other to handle the civil investigatory, or "watchdog," function. ${ }^{14}$ In those few instances in which a prosecutor

8. 22 Cal. 3d at 611-15, 586 P.2d at 933-36, 150 Cal. Rptr. at 452-55. See 1 Debates AND Proceedings of the Constitutional Convention of the State of California 308-18 (1880); California Constitution Revision Commission, Proposed Revision of the CallFORNiA CONSTITUTION, Part 5, at 22 (1971). In response to the contention that the courts are without authority to alter grand jury procedures, the majority argued that article I, $\$ 14$ of the constitution, providing that felonies be prosecuted "as provided by law," gives the courts concurrent authority to regulate grand juries by virtue of their ability to make law by judicial decision.

9. 22 Cal. 3d at 619,586 P.2d at 939,150 Cal. Rptr. at 458.

10. Michigan is the only other state in which an indicted defendant is enlitled to a postindictment preliminary hearing. See People v. Duncan, 388 Mich. 489, 201 N.W.2d 629 (1972). Furthernore, the Michigan Suprene Court's decision was not constitutionally grounded.

11. See, e.g., 22 Cal. 3d at $605-06,586$ P.2d at 930, 150 Cal. Rptr. at 449 (3.9\% of felony prosecutions from 1968 to 1971 initiated by indictunent).

12. See Note, Grand Jury System Modified: Hawkins v. Superior Court, 6 WASH. ST. U.L. Rev. 343, $347 \mathrm{n} .37$ (1979) (imformal survey of four major counties indicates that use of the indictment procedure lias fallen off dranatically).

13. After the Hawkins decision was announced, Assemblyman John Knox introduced a bill codifymg the Hawkins rule by providing procedures for a postindictment hearing. A.B. 500, Cal. Legis. Reg. Sess. (1979-80). The Assembly passed an amended version on April 16, 1979, but as of April 1980, the bill was stalled in the Senate Judiciary Committee.

14. The state constitution, amended in 1974, allows the drawing of more than one grand jury. CAL. CONST. art. $1, \S 23$.

The grand jury's watchdog function is a statutory creation. See CAL. Penal Code $\$ \$ 925-$ 933.5 (West 1970). The grand jury lias the power to initiate and conduct investigations of certain 
feels it is worth the trouble to endure both a grand jury and a preliminary hearing, for example, to toll the statute of limitations when the defendant cannot be located, the use of a grand jury may serve the state's legitimate interests without depriving the individual of important procedural rights. ${ }^{15}$

A separate grand jury to act as a "watchdog" over local government activity could devote all its time and resources to this role, without beimg sidetracked by indictment duties. Some minor legislative changes aimed at increasing its role ${ }^{16}$ might go a long way toward making it more useful than it has been in the past.

An unresolved issue after Hawkins is the effect to be given an indictment at a postindictment preliminary hearing. Hawkins directs that the indictment be refiled as a complaint. This implies that the indictment would carry no weight, which seems the result most consistent with the opinion. Or, the magistrate might consciously or unconsciously give the indictment some presumptive validity as a probable cause showing. This result would provide some incentive for a prosecutor to go to the grand jury, but he would still face the burden of presenting his case at the preliminary hearing. Finally, the indictment might be given full effect, even if the preliminary hearing does not result in a showing of probable cause. This was the position of the attorney general's office after the Hawkins decision. ${ }^{17}$ This result is highly doubtful, for it would negate the preliminary learing's primary function of insuring that probable cause exists.

People v. Wheeler ${ }^{1}$ and Rubio v. Superior Court. ${ }^{2}$ In People v.

local government operations, and to make a report of its findings. See generally Petersen, The California Grand Jury System: A Review and Suggestions for Reform, 5 PAC. L.J. 1 (1974).

15. One problem does remain-that of protecting witness identity, when desirable, by closing the preliminary hearing to the public. Presently, on defendant's request, the public can be excluded from a preliminary hearing. See CAL. PENAL CODE $\$ 868$ (West 1970). The post-Hawkins bill introduced by Asseinblyman Knox, see note 13 supra, would have allowed the prosecution, the court, or the defendant to cause a preliminary hearing to be closed to the public. This provision was deleted from the version of the bill passed in the Assembly.

16. See Petersen, note 14 supra, for an excellent summary of potential legislative reforms designed to increase the grand jury system's value and efficiency in both its criminal and civil roles.

17. Comments by Deputy Attorney General Clifford $K$. Thompson, Commonwealth Club of California section meeting, in San Francisco (Jan. 18, 1979).

1. 22 Cal. 3d 258, 583 P.2d 748, 148 Cal. Rptr. 890 (1978) (Mosk, J.) (4-1-2 decision).

2. 24 Cal. 3d 93, 593 P.2d 595, 154 Cal. Rptr. 734 (1979) (Mosk, J.) (2-2-3 decision). 
Wheeler, two black defendants stood accused of murdering a white shopkeeper in the course of a robbery. Although they had survived challenge for cause, all blacks in the venire were struck by peremptory challenge of the prosecutor. An all-white jury subsequently convicted the defendants. The Cahifornia Supreme Court, im the first explicit break with the United States Supreine Court decision in Swain v. Alabama, ${ }^{3}$ held that the prosecutor's conduct violated the defendants' right to trial by a jury drawn from a representative cross-section of the community, as guaranteed by article I, section 16 of the California Constitution. ${ }^{4}$ The court held that when a reasonable inference can be drawn that a pereinptory challenge was prompted solely by group bias, the allegedly offending counsel must, at risk of retrial, satisfy the court that the challenge was exercised on grounds reasonably relevant to the particular case. While the Wheeler holding does not grant to any litigant "the right to a jury that mirrors the demographic composition of the population, or necessarily includes members of his own group, or indeed is composed of any particular individuals," neither may any litigant exercise his peremptories to thwart "as near an approximation of the ideal cross-section of the community as the process of random draw permits."5

Writing for the inajority in a case he termed one of first impression, ${ }^{6}$ Justice Mosk emphasized that the right to trial by jury, under federal and California law, entails the right to have a verdict rendered by impartial jurors. The court stressed the important function a representative cross-section serves in cancelling out the group biases prospective jurors may bring to bear in their deliberations. The court held that in California, the right to trial by jury drawn from a representative cross-section of the community is guaranteed equally and independently by the sixth anendment to the Federal Constitution and by arti-

3. 380 U.S. 202 (1965). The United States Supreme Court, upholding the conviction of a black defendant on a rape charge by an all-white jury from which six blacks had been percmptorily struck by the prosecutor, held that the prosecution's peremptory challenge of black prospective jurors without explanation does not constitute a denial of equal protection under the 14th amendment. In the fifteen years smce $S$ wain was decided no defendant has sustained the burden of showing a systematic discriminatory use of the peremptory challenge. See Annot., Use of the Peremprory Challenge to Exclude from Jury Persons Belonging to a Class or Race, 79 A.L.R.3d 14 (1977). $\S 16$.

4. "Trial by jury is an mviolate right and shall be secured to all. . . ." CAL. Const. art. I,

5. 22 Cal. 3d at 277, 583 P.2d at 762, 148 Cal. Rptr. at 903.

6. According to Justice Richardson, the majority was incorreet in terming Wheeler a case of first impression. Id. at 290, 583 P.2d at 770, 148 Cal. Rptr. at 912 (Richardson, J., dissenting). Attacks on discriminatory challenges had reached the supreme court before Wheeler, but the Swain presumption was upheld. See People v. Floyd, 1 Cal. 3d 694, 464 P.2d 64, 83 Cal. Rptr. 608 (1970). 
cle I, section 16 of the California Constitution. ${ }^{7}$ As the court noted, this representativeness may be compromised at tluree stages: (1) in the compilation of eligible juror rolls; (2) in the disqualification or exclusion of jurors on competency grounds; and (3) in the exercise of challenges for cause and peremptory challenges. While the United States Supreme Court limited the impact of federal constitutional considerations to the first stage, Wheeler imposes new limits, based on the California Constitution, on the third stage. Although acknowledging that peremptory challenges may promote jury impartiality by eliminating those jurors holding extreme and potentially prejudiced views, the court reasoned that the use of peremptory challenges to exclude potential jurors solely on the grounds of group bias upsets the demographic balance of the venire, and enables other perspectives to have a disproportionate impact in the deliberation process. This results in a less than fair and impartial jury. ${ }^{8}$ California thus becanie the first American jurisdiction to limit significantly the discriminatory exercise of peremptory challenges.?

Seeking to preserve the usefulness of the peremptory by shielding it from exhaustive examination, the court stressed the presumption that a party exercismg the peremptory challenge does so on a "constitutionally permissible ground." 10 But where it appears one party is using the challenge impermissibly to strike group members, the aggrieved party may raise a timely objection, and establish to the trial court's satisfaction the "reasonable inference . . . that peremptory challenges are bemg used on the ground of group bias alone."11 One relevant factor to be considered is whether tlue defendant is a member of the group discriminated against and his victim is not. ${ }^{12}$ If the imference can be drawn, the trial court then shifts the burden to the allegedly offending party to show that the jurors struck harbored specific bias "reasonably relevant" to the case on trial, its parties, or its witnesses. ${ }^{13}$ In Wheeler, the trial court's failure to require an explanation from the prosecutor after a prima facie showing of improper use had been made was prejudicial error per se. ${ }^{14}$ The conviction was reversed and the case re-

7. 22 Cal. 3d at 272,583 P.2d at 758,148 Cal. Rptr. at 899 .

8. Id. at 276,583 P.2d at 761,148 Cal. Rptr. at 902.

9. Since Wheeler, Massachusetts has become the second state to limit peremptory challenges. See Commonwealth v. Soares, 79 Mass. App. Ct. Adv. Sh. 617, 387 N.E.2d 499 (1979). The Massachusetts Supreme Judicial Court drew heavily upon the Wheeler decision. For a discussion of the two cases, see Note, Defendant's Right to Object to Prosecutorial Misuse of the Peremptory Challenge, 92 HaRv. L. Rev. 1770 (1979).

10. 22 Cal. $3 \mathrm{~d}$ at 278,583 P.2d at 762, 148 Cal. Rptr. at 904.

11. Id. at 281,583 P.2d at 764, 148 Cal. Rptr. at 906.

12. Id., 583 P.2d at 764, $148 \mathrm{Cal}$. Rptr. at 905-06.

13. Id. at 282,583 P.2d at $765,148 \mathrm{Cal}$. Rptr. at 906 .

14. Id. at 283,583 P.2d at 766,148 Cal. Rptr. at 907. 
manded for retrial. ${ }^{15}$

In dissent, Justice Richardson, with Justice Clark concurring, decried the "sweeping procedural changes" in the peremptory challenge wrought by the majority holding in Wheeler. He predicted the new principles will present complex practical difficulties im admimistration, prolonging the present "lengthy" voir dire without vindicating the defendant's right to an impartial trial. ${ }^{16}$ The dissent characterized the majority's "simple, straightforward test" as so vague as to be no standard at all. ${ }^{17} \mathrm{He}$ criticized the majority's holding for its lack of legal precedent and misperception of the jury process. The purpose of jury selection, the dissent argued, is not to mix "representative groups 'so that the respective biases of their inembers, to the extent they are antagonistic, will tend to cancel each other out." "18 Impartiality is not assured, he said, by balancing a representative array of biases.

Wheeler may inhibit the scrupulous attorney from exercising peremptories, particularly as long as the contours of group affiliation remain open to speculation. If an intuited "specific bias" cannot be articulated and supported, an attorney may be wary of exercising peremptories against group members. Even the inost skillful voir dire may not prove successful im ferreting out biases that may affect a verdict. It has been noted that "individuals being interrogated are likely to answer questions according to whether they want to serve or not, and may not admit to certain prejudices, especially race and rehgious prejudices." 19 Nonetheless, the court in People v. Johnson, ${ }^{20}$ a companion case to

15. The court limited its holding to Wheeler and its companion case, People v. Johnson, 22 Cal. 3d 296, 583 P.2d 774, 148 Cal. Rptr. 915 (1978), and to any defendant then or thereafter under a death sentence. 22 Cal. $3 d$ at 283 n.31, 583 P.2d at 766 n.31, 148 Cal. Rptr. at 907 n.31. The question of Wheeler's applicability to civil cases was reserved for later determination, $i d$. at $282 \mathrm{n} .29,538 \mathrm{P} .2 \mathrm{~d}$ at $765 \mathrm{n} .29,148 \mathrm{Cal}$. Rptr. at $906 \mathrm{n} .29$, although nothing in the opinion suggests why the rule should not be so extended.

16. Id. at 288, 583 P.2d at 769, $148 \mathrm{Cal}$. Rptr. at 910 (Richardson, J., dissenting).

17. While acknowledging that standards so variable would necessarily require "trial judges to make difficult and often close judgments," the majority expressed confidence in the judges' appreciation of the trial process, broad judicial experience, and first-hand observation of voir dire in an individual case. Id. at 281, 583 P.2d at 764, 148 Cal. Rptr. at 906.

18. Id. at 292, 583 P.2d at 771, 148 Cal. Rptr. at 913 (Richardson, J., dissenting).

19. J. VAN Dyke, JuRy Selection Procedures 163 (1977).

20. 22 Cal. 3d 296, 583 P.2d 774, 148 Cal. Rptr. 915 (1978). In Johnson, a black defendant was convicted of the rape of a white woman after the prosecution had struck all blacks from the jury by peremptory challenge. The prosecutor defended his action on the ground that prosecution witnesses had made racially prejudicial remarks that were likely to be disclosed to the jury. The prosecutor explained:

As long as I had peremptory challenges I intended to peremptorily excuse black jurors in this case because I felt that some of my witnesses. . . would show a prejudice against the black people and I felt there was no way to voir dire . . . [to] identify a black person who could with objectivity sit on a jury where he might hear his race referred to as, for instance, "nigger."

Id. at 299,583 P.2d at $775,148 \mathrm{Cal}$. Rptr. at 916. The court deemed this "decision-making by 
Wheeler, maimtained that a good faith attempt must be made to identify the bias that intuition may suggest. Although voir dire may be inadequate to prove actual bias, the court perhaps believed that it might be adequate to develop an articulable, colorable claim of specific bias.

Trials are also likely to be delayed, since Wheeler appears to require extensive voir dire to support a foundation for a finding of "specific bias." Johnson underscores the court's view that peremptories may be exercised legitimately only after extensive_- "good faith," nondesultory-voir dire. ${ }^{21}$ Such an expansion of voir dire overrules, albeit silently, the "well settled [rule] in this state that a juror may not be examined on voir dire solely for the purpose of laying the foundation for the exercise of a peremptory challenge."22 This rule fostered a reliance by counsel on intuition and stereotypes that minimized the voir dire time necessary to enable counsel to exercise the peremptory. Wheeler now expressly prohibits the use of many of these subjective indicators.

Because the court had no doubt that blacks constitute a cognizable group within the meaning of the representative cross-section rule, it saw no need to identify other groups that would necessarily be cognizable for jury composition purposes. ${ }^{23}$ However, the court suggested that the demographic balance of the venire would be upset where "members of an identifiable group distmguished on racial, religious, ethuic, or similar grounds" were peremptorily struck on that basis alone. ${ }^{24}$ The Wheeler court thus left open the possibility that a party's exercise of a peremptory challenge might be questioned where the excluded jurors shared even the most tenuous affiliation. Less than a year later, the supreme court had occasion to explore further the cognizability of groups in jury selection in Rubio v. Superior Court.

Defendant Rubio, a convicted felon "of Mexican descent," was charged with one count of inurder committed while he was incarcerated in prison. He inoved to quash the petit jury venire on the ground that it contamed neither ex-felons nor resident aliens. ${ }^{25}$ The trial court

racial stereotype, a technique that should be anathema in our courts." Id., 583 P.2d at 775, 148 Cal. Rptr. at 917 . Johnson thus instructs that peremptories may be exercised legitimately only after extensive (good faith, nondesultory) voir dire, even where the facts of the case provide some basis for exercising peremptories on grounds of group affiliation.

21. Id. at 300, 583 P.2d at 775, 148 Cal. Rptr. at 917.

22. People v. Crowe, 8 Cal. 3d 815, 830, 506 P.2d 193, 203, 106 Cal. Rptr. 369, 379 (1973) (quoting People v. Rigney, 55 Cal. 2d 236, 244, 359 P.2d 23, 27, 10 Cal. Rptr. 625, 629 (1961)).

23. 22 Cal. 3 d at 280 n.26, 583 P.2d at 764 n.26, 148 Cal. Rptr. at 905 n.26.

24. Id. at 276,583 P.2d at $761,148 \mathrm{Cal}$. Rptr. at 902.

25. Equal protection challenges were also made against the statutory exclusion of ex-felons and resident ahens from jury service. These challenges were rejected on the ground that the state 
denied the motion and Rubio sought a writ of prohibition to review the trial court's order.

Reiterating its Wheeler holding, the supreme court nonetheless held that the right to trial by a jury drawn from a representative crosssection of the cominunity is not denied by the exclusion of ex-felons and resident aliens. For guidance in deterniming whether an asserted group is "cognizable" for purposes of the representative cross-section rule, the court offered a two-part test. First, group meinbers must share a common perspective arising from their life experiences in the group such that their group affiliation imparts a "common social or psychological outlook on human events."26 Second, the composition of the group must be such that "no other members of the community are capable of adequately representing the perspective of the group assertedly excluded." 27 This test is consistent with the representative cross-section rule because the goal of the rule, the court explained, is "to enhance the likelihood that the jury will be representative of significant community attitudes, not of groups per se."28

Applying the test to the groups allegedly excluded in the case before it, the court found that ex-felons and resident aliens satisfied the first requirement, but not the second. Ex-felons share the experience of deprivation of their personal liberty by the state and stigina in the community upon their release due to their former status. But other classes of persons eligible for jury service, such as convicted misdemeanants and youthful offenders who have been confined in the custody of the Youth Authority, have had similar experiences of loss of personal liberty followed by social stigmatization. ${ }^{29}$ Resident aliens share the experience of being excluded from the political processes of the nation by the government and of being the victims of both official and unofficial discrimination by the citizenry. But naturahized citizens have also experienced this exclusion and discrimination, being resident aliens themselves at one time. Since neither ex-felons nor resident aliens qualified as a cognizable group, their exclusion from the petit jury venire did not deny Rubio his right to a trial by a jury drawn from a representative cross-section of the community. ${ }^{30}$

In dissent, Justice Tobriner denounced the second part of the majority's two-part cognizability test as "vicarious" representation for

has a legitimate purpose in keeping these classes of people off juries. $24 \mathrm{Cal} .3 \mathrm{~d}$ at 101-04, 593 P.2d at 600-02, 154 Cal. Rptr. at 739-41.

26. Id. at 98,593 P.2d at 598, 154 Cal. Rptr. at 737.

27. Id.

28. Id. (italics in original).

29. Id. at 98-99, 593 P.2d at 598, 154 Cal. Rptr. at 737.

30. Id. at 100, 593 P.2d at 600 , I54 Cal. Rptr. at 738. 
which there was neither United States nor Cahfornia precedent. ${ }^{31}$ Excluding a group from jury service on the basis that its views are already represented, the justice said, is as contrary to the democratic ideal as denying a class of citizens the right to vote for the same reason. By treating the views of groups as fungible, the majority ignored the complexities and subtleties of human experience. A fair cross-section of the community cannot be achieved when groups are excluded on the basis of representation of their views by other groups, because the relative proportion of persons holding various views is thereby distorted. ${ }^{32}$ In addition, the majority contradicted itself when it assumed that the views of ex-felons are adequately represented, but at the sane time, admitting im its equal protection analysis that the state has a legitimate reason for excluding ex-felons because they harbor a unique, contimuing resentment against the system. ${ }^{33}$

Although in Rubio the court has attempted to establish a test that will foretell whicli groups must not be excluded if tlie jury is to be representative, the imprecision of the test may make it unworkable. The Rubio test hinges on identification of groups whose attitudes are "sigmificant," a term open to some question, as Justice Tobrmer's dissent deinonstrates. If "significant" is broadly defined, the peremptory may effectively be eliminated, since its exercise acts to render the jury more hoinogeneous than the population at large. If the term is narrowly defined, the courts may come to regard group attitudes as fungible, and the protection afforded by the representative cross-section rule may be diluted. Judicial determination of "cognizability" on a case-by-case basis appears likely. ${ }^{34}$ The courts may ultimatcly decide that the approach adopted by the Massachusetts Supreme Judicial Court, ${ }^{35}$ under which the cognizable groups are limited to those regarded as "suspect" classifications under equal protection rubric, is administratively superior. Limiting the Wheeler protection to "suspect" classifications would make the evaluation of the "significance" of various community attitudes the Rubio case now imposes unnecessary.

31. Id. at 107, 594 P.2d at 601, 154 Cal. Rptr. at 743 (Tobriner, J., dissenting).

32. Id. at 109-10, 594 P.2d at 605, 154 Cal. Rptr. at 744 (Tobriner, J., dissenting).

33. Id. at 110-11, 594 P.2d at 606-07, 154 Cal. Rptr. at 764 (Tobriner, J., dissenting).

34. Since Rubio, one California court of appeal has decided that the "less educated," "blue collar workers," "young adults," and "low income" persons are not constitutionally "cognizable," and that their exclusion from a grand jury did not deprive the defendant of his right to an impartial trial. People v. Estrada, 93 Cal. App. 3d 76, 155 Cal. Rptr. 731 (1st Dist. 1979).

35. Commonwealth v. Soares, 387 N.E.2d 499. The Massachusetts Supreme Judicial Court hmited the group characteristics cognizable for representative cross-section purposes to race, sex, creed, or national origin. Id. at 516 . 
People v. Tanner. ${ }^{1}$ The supreme court, on a rehearing, interpreted section 1203.06 of the California Penal Code, ${ }^{2}$ which prohibits a court from grantimg probation to persons convicted of using a firearm in the commission of certain crimes. The court held that this section was intended to abrogate the trial court's general power under section $1385^{3}$ to strike a finding that a gun had been used and grant probation. However, Tanner was not required to serve a second term because he had already complied with the unauthorized conditions of his probation and because of the unusual post-conviction proceedings by the court itself.

The rehearing of the case was triggered, at least indirectly, by an article in the Los Angeles Times alleging that the release of the Tanner decision was bemg delayed until after the Chief Justice's confinnation vote, which was scheduled to take place on the day the article was printed. ${ }^{4}$ The alleged reason for the delay was that her position on the case might adversely affect her confirmation. The court subsequently reported a decision of the Tanner case in which, by a 4-3 majority, it confirmed the trial court's decision to grant probation under section 1385 despite the restriction seemingly placed on its ability to do so by section 1203.06. ${ }^{5}$ There followed a barrage of public comment denouncing botli the court's tactics and its opinion. The furor surroundmg the court's early adjudication of the case prompted Chief Justice Bird to seek review by the Commission on Judicial Performance, which ultimately found no wrongdoing. It also prompted a rehearing, in

1. 24 Cal. 3d 514, 596 P.2d 328, 156 Cal. Rptr. 450 (1979) (Clark, J.) (4-3 decision).

2. Cal. Penal Code $\$ 1203.06$ (West Supp. 1979) provides in pertinent part:

Notwithstanding the provisions of Section 1203:

(a) Probation shall not be granted to, nor shall the execution or imposition of sentence be suspended for, any of the following persons:

(1) Any person who personally used a firearm during the commission or attempted commission of any of the following crimes:

(iii) Robbery, in violation of Section 211.

3. Cal. PENAL CODE $\$ 1385$ (West 1970) provides in pertinent part: "The court may, either of its own motion or upon the application of the prosecuting attorney, and in furtherance of justice, order an action to be dismissed." This section has been construed to authorize a trial court to strike a count or an allegation from the accusatory pleadings even where the court or a jury has found the defendant guilty of the count or has found the allegation to be true. People v. Burke, 47 Cal. 2d 45, 50-51, 301 P.2d 241, 244-45 (1956).

4. Los Angeles Times, Nov. 7, 1978, $\$ 1$, at 6, col. 2.

5. People v. Tanner, 23 Cal. 3d 16, 587 P.2d 1112, 151 Cal Rptr. 299 (1978) (Tobriner, J.) (4-3 decision), rev'd on rehearing, 24 Cal. 3d 514, 596 P.2d 328, 156 Cal, Rptr. 450 (1979). The majority opimion, dated December 22,1978 , held that $\$ 1203.06$ did not amount to a limitation on trial court discretion under $\$ 1385$. 
which the court changed its opinion; Justice Mosk provided the swing vote.

The Tanner case began when Tanner was convicted of using a firearm in a robbery. This satisfied the "use" requirement of section 1203.06. Nevertheless, the trial judge struck the jury's finding that a firearm had been used, suspended execution of the sentence, and placed Tanner on probation, relying on the general power to do so granted him under section 1385.

On the rehearing, the inajority of the supreme court rejected the notion that courts are inherently or constitutionally vested with a final authority to fix sentences or to impose penalty-enhancing sanctions for proscribed conduct. It stated that the issue had to be determined by construction of the relevant statutes. The majority held that the legislature's failure to insert any language providing for exceptions to seetion 1203.06 indicated an intent to eliminate judicial discretion in cases falling within the section.

The court further noted the rule of statutory construction that a specific provision concerning a particular subject must govern a general provision to the contrary whenever both provisions apply. ${ }^{6}$ As a specific provision relating to the limited power of dismissal for probation purposes, section 1203.06 was held to prevail over section 1385, which confers a general power of dismissal.

Notwithstanding its substantive holding, however, the court decided that a second incarceration for Tanner would be unjust. At the time of the rehearing Tanner had already compled with his conditions of probation, and the ainbiguity of the law preceding the final resolution of the issue of judicial discretion ${ }^{7}$ made the injustice of requiring him to serve a second terin seem particularly harsh.

Justices Tobriner and Newman and Chief Justice Bird concurred in not requiring Tanner to serve a second sentence, but each separately dissented from the majority's holding that the trial court did not have the power to strike the "use" finding. The Chief Justice alone viewed the issue as one of constitutional dimension. She agreed with the majority that section 1203.06 was intended to abrogate the discretion granted under section 1385; however, she considered this a legislative intrusion upon the court's power over the adjudicatory process in violation of article III, section 3 of the California Constitution. She further argued that withdrawing discretion from the court in such a manner would effectively vest the power to strike a "use" finding solely in the prosecutor, who renained free to omit the allegation of "use" from the

6. E.g., Rose v. California, 19 Cal. 2d 713, 123 P.2d 505 (1942).

7. Justice Tobriner's dissent illustrates the uncertainty in the proper construction of § 1203.06. See text accompanying notes 9-10 infra. 
pleadings or to strike it under a prosecutor's section 1385 motion. Such a result would tip the balance of power significantly in the prosecutor's favor in plea-bargaining situations, to the detriment of defendants who might otherwise have fought the charges and won in court. In addition, it would have the effect of reallocating the power to omit a "use" finding and mitigate a sentence, instead of eliminating this power altogether as the legislature wished to do.

Justice Tobriner disagreed with the majority's construction of the statute and pointed to prior authorities ${ }^{8}$ which held that mandatory sentencing statutes should not be interpreted as elimmating the powers accorded by section 1385 unless the legislature had done so by exphicit statutory language. Section 1203.06 was made applicable "[n]otwithstanding the provisions of Section 1203"9 rather than "[n]otwithstanding any other provision of law" as had been specified in other "no probation" statutes. ${ }^{10}$ Justice Tobriner therefore argued that the legislature intended section 1203.06 to repeal the trial court's discretion under section 1203, with no effect on the power to strike under section 1385. He also noted that the majority's result was inconsistent with its construction of section 1203.06. By not requiring a "mandatory" prison sentence in Tamier's case, the majority was effectively underscoring the traditional power of courts to exercise discretion in sentencing.

Justice Newman, concurring with Justice Tobriner, based his conclusion on a careful review of the legislative history of section 1203.06. He expressed the fear that the majority's holding was affected by the public outcry attending the case, which was directed at least as much at the court's delayed release of its original opinion as at the substantive content of that opinion.

The Tanner case may be better remembered for the political tumult it raised and for the fact that the supreme court felt compelled to rehear the case than for its substantive holding. This may be justified in light of the fact that the case was decided differently on the first hearing and emerged as a 4-3 decision, with three separate dissents regarding its substance, on the rehearing. The majority opinion is, on its face, an affirmation of the California legislature's power to neutralize court discretion in sentencing and a ruling that the legislature did just that with section 1203.06. On a political level, it demonstrates that the

8. People v. Burke, 47 Cal. 2d 45, 301 P.2d 241 (1956); People v. Dorsey, 28 Cal. App. 3d 15, 104 Cal. Rptr. 326 (4th Dist. 1972).

9. Cal. Penal Code \& 1203.06 (West Supp. 1979); see note 2 supra. Cal. Penal Code $\S 1203$ (West Supp. 1979) is a general "no probation" statute giving the trial court power to grant probation in unusual circumstances in the interests of justice.

10. E.g., CAL. PenAl Code $\S \S 1203.08-.09$ (West Supp. 1979). 
supreme court is not imdependent of the political process, but can be influenced by it so far as to rethink its decisions when confronted with hostile public opinion. The danger this poses is the loss of an independent judiciary as a force to counterbalance the power of the legislature, the executive, and ad hoc public opinion. ${ }^{11}$ As a matter of political wisdom, solne concessions to public opinion nay be required to preserve the court's credibility. However, judicial credibility also depends on a perception that the court is willing to stand by its decisions once they are made. Seen in this light, the rehearing of Tanner was a judgment call, illustrative of the uncomfortable position a court finds itself in when its legal instincts fail to square with prevailing notions of what the law should be.

People v. Woodard. ${ }^{1}$ The California Supreme Court held that a prosecutor may not, pursuant to Evidence Code section $788,{ }^{2}$ freely impeach a nonparty criminal defense witness' credibility with evidence of the witness' prior felony convictions. Rather, upon the defendant's notion, the trial judge must balance the potential prejudicial effect to the defendant resulting froin adinission of the evidence ${ }^{3}$ against the proba-

11. According to Professor Tribe, "[w]e must combat an imperial judiciary, but we need an independent judiciary to avoid the even greater dangers of an imperial executive and an imperial legislature." Kang, The Decline of California's Vendetta-Ridden Supreme Court, 10 CAL. J. 343, 344 (1979).

1. 23 Cal. 3d 329, 590 P.2d 391, 152 Cal. Rptr. 536 (1979) (Bird, C.J.) (6-1 decision).

2. CAL. Evid. CoDE $\S 788$ (West 1966): "For the purpose of attacking the credibility of a witness, it may be shown . . . that he has been convicted of a felony . . .."

3. The Woodard majority cite as potentially prejudicial (1) the danger of resolution of reasonable doubts against the accused because he associates with felons, and (2) the possibility that the jury may act arbitrarily and give little weight to a felon's testimony. 23 Cal. $3 \mathrm{~d}$ at 338,590 P.2d at 396, 152 Cal. Rptr. at 541. However, Johnson testified without contradiction that Woodard was an acquaintance and not a friend, thus perhaps lessening fears of guilt by association. Id. at 334, 590 P.2d at 393, 152 Cal. Rptr. at 538. The majority also note tlat jury deliberations took six hours, and the jury requested that Johnson's testimony be reread. Id. at 342, 590 P.2d at 398, 152 Cal. Rptr. at 543 . While bolstering the majority's contention that the case was extremely close, and therefore that the felony conviction evidence might Lave indeed prejudiced Woodard, these facts undercut any concern that the jury arbitrarily dismissed Johnson's testimony. One infers, then, that an appellant need only allege, rather than attempt to demonstrate, the evidence's prejudicial effect.

Other factors bearing on prejudicial effects imclude imdue consumption of time, confusion of issues, and risk that the defendant (and now any witness) may decline to testify. Id. at 337, 590 P.2d at 395, 152 Cal. Rptr. at 540. Evidence of convictions for the same or similar offense as that charged inay also be prejudicial. People v. Rist, 16 Cal. 3d 211, 219, 545 P.2d 833, 838, 127 Cal. Rptr. 457, 462 (1976). These factors are not germane to the instant case. 
tive value of the convictions on the issue of truthfulness. ${ }^{4}$ This balancing prior to admitting the evidence satisfies the requirements of People v. Beagle ${ }^{5}$ and Evidence Code section 352 . $^{6}$

The defendant, Woodard, was arrested and tried for robbery. Identity of the perpetrator was the key issue in the trial. ${ }^{7}$ A defense witness, Johnson, testified that he observed the crime, knew Woodard, and was certain that the robber was someone else. The prosecution, however, imtroduced evidence over the defendant's objection of Johnson's prior convictions for voluntary manslaughter and for a felon's possession of a concealable firearm. The jury, obviously discounting Johnson's testimony, convicted Woodard of second degree robbery. The supreme court reversed im a decision which expands the Beagle holding and makes it nore doctrinaire, and which may have finally gutted Evidence Code section 788.

Woodard extends Beagle's reach by applying its doctrine for the first time to a witness other than a testifying criminal defendant. The extension, however, was not unanticipated. In Beagle, Chief Justice Wright wrote, "The defendant must weigh the danger of impeachment by the introduction of prior convictions for every witness he calls for the defense." Subsequently, the supreine court emphasized that Beagle balancing was particularly warranted if the witness was also a crimmal defendant, implying Beagle was operative elsewhere, too. ${ }^{9}$ Moreover, the supreme court drew a parallel to Beagle in an attorney disciplinary proceeding, but stopped short of actually applying the balancing test. ${ }^{10}$ One question raised by Woodard's inclusion of nonparty defense witnesses, then, is where the prospective outer limits of Beagle he. The Woodard nnajority expressly assert that Beagle applies to all proceedings, criminal or civil, and to all witnesses, party or nonparty. ${ }^{11}$ That stateinent may suggest a broader application than the Beagle line of cases would permit. A common theme runs throughout those cases: undue prejudice is most acute when an individual's loss of liberty is at

4. Crimes such as perjury, burglary, and robbery are considered probative of the issue of truthfulness. A conviction's remoteness im time lessens its probative force. $23 \mathrm{Cal} .3 \mathrm{~d}$ at 336,590 P.2d at 395, 152 Cal. Rptr. at 540.

5. 6 Cal. 3d 441, 492 P.2d 1, 99 Cal. Rptr. 313 (1972).

6. CAL. Evid. Code $\S 352$ (West 1966).

7. The problem in Woodard was especially acute smce Johnson was the only defense witness on identity.

8. 6 Cal. 3d at 453-54, 492 P.2d at 8, 99 Cal. Rptr. at 320 (emphasis added).

9. People v. Antik, 15 Cal. 3d 79, 97, 539 P.2d 43, 55, 123 Cal. Rptr. 475, 487 (1975) (emphasis added).

10. See Schullman v. State Bar, 10 Cal. 3d 526, 539, 516 P.2d 865, 874, 111 Cal. Rptr. 161, 170 (1973) (hearing officer's handling of record of prior disciplinary action against attorney).

11. $23 \mathrm{Cal}$. $3 \mathrm{~d}$ at $338-39,590 \mathrm{P} .2 \mathrm{~d}$ at $396,152 \mathrm{Cal}$. Rptr. at 541. 
stake. $^{12}$ Beagle's future impact in the civil arena, then, is uncertain; courts might find the prejudicial effect of conviction evidence to outweigh credibility relevance only when the sanctions threatened in the case are sufficiently severe. ${ }^{13}$

Woodard also makes the Beagle doctrine more a matter of set, articulated law than a matter of trial court discretion. The majority's finding as a matter of law that Johnson's prior felony convictions were without probative value, and that therefore the trial court need not have reached the Beagle balancing stage, imdicates the shift away from Beagle's own admonition that "[w]e do not purport to establish rigid standards to govern." 14 This transformation in favor of setting rules of application can be tracked through the supreme court's changing attitude toward trial judges' discretion in the Beagle area. ${ }^{15}$ Beagle stated that "each instance [whether to admit the evidence or not] must depend on the sound exercise of judicial discretion." 16 People v. Antik later declared that "discretion is not absolute and must be carefully exercised." 17 Subsequently, People v. Rist warned that "judicial discretion is by no means a power without rational bounds" 18 after noting that Beagle was not being adhered to by lower courts. ${ }^{19}$ Finally, Woodard mandates that if the elements of a prior conviction fail to satisfy Evidence Code section 786 (only character traits bearing on honesty and veracity are admissible), then judicial discretion is unavailable, and the evidence is to be excluded at the outset. ${ }^{20}$

12. Id. at 340, 590 P.2d at 397, 152 Cal. Rptr. at 542; People v. Antik, 15 Cal. 3d at 98, 539 P.2d at 55, 123 Cal. Rptr. at 487; People v. Beagle, 6 Cal. 3d at 454, 492 P.2d at 8, 99 Cal. Rptr. at 302 ("fact that the witness may also be the [criminal] defendant makes the choice more difficult").

See People v. Carr, 32 Cal. App. 3d 700, 704, 108 Cal. Rptr. 216, 218 (5th Dist. 1973) (application of Beagle to prosecution witness) (approved in Woodard, 23 Cal. 3d at 339, 590 P.2d at 396, 152 Cal. Rptr, at 541).

13. Undue prejudice may be a function of the relative severity of the sanction threatened: "the factors to be weighed may differ depending upon the nature of the case or the party." Id. at 339, 590 P.2d at 396, 152 Cal. Rptr. at 541. Assuming this, Beagle may reach civil cases with "severe" potential sanctions such as the revocation of a professional license in Schullman.

14. 6 Cal. $3 \mathrm{~d}$ at 453,492 P.2d at 8, 99 Cal. Rptr. at 320.

15. Alternately, this shift can be traced through the court's approach to the prejudicial effect of a witness' prior convictions for a sane or similar offense to that presently charged (i.e., the concern that the jury might infer that if he did it once, he probably did it again). Beagle stated that same or similar prior convictions were to be used "sparingly." Id. People v. Rist then held that such prior offense evidence was inadmissible if there were other prior convictions of the witness available. $16 \mathrm{Cal}$. 3d at 219, 545 P.2d at 838, $127 \mathrm{Cal}$. Rptr. at 462 . Now two recent cases completely prohibit impeachment by way of sane or similar prior felonies. People v. Spearman, 25 Cal. 3d 107, 599 P.2d 88, 158 Cal. Rptr. 1 (1979); People v. Fries, 24 Cal. 3d 222, 594 P.2d 19, 155 Cal. Rptr. 194 (1979).

16. 6 Cal. $3 \mathrm{~d}$ at 453,492 P.2d at 8,99 Cal. Rptr. at 320.

17. 15 Cal. $3 \mathrm{~d}$ at 98,539 P.2d at 55, $123 \mathrm{Cal}$. Rptr. at 487.

18. 16 Cal. $3 \mathrm{~d}$ at 219,545 P.2d at $839,127 \mathrm{Cal}$. Rptr. at 463 .

19. Id. at 221, 545 P.2d at 840, 127 Cal. Rptr. at 464 .

20. $23 \mathrm{Cal} .3 \mathrm{~d}$ at 335,590 P.2d at $394,152 \mathrm{Cal}$. Rptr. at 539. 
Finally, Woodard may be the death knell for Evidence Code section 788. The Beagle doctrine resulted from the modification of section 788 by section 352 (general grant of authority to trial judge to exclude prejudicial, though probative, evidence). ${ }^{21}$ The Woodard majority, however, cite Evidence Code section $786^{22}$ as authority that in general only character traits bearing on honesty and veracity are relevant to credibility. ${ }^{23}$ This applies with equal force, so the supreme court reasons, to instances where felony convictions are used for impeachment purposes. This is a radical change from the court's unanimous view in Schullman v. State Bar that although convictions might be too prejudicial to admit in a given case, all "prior convictions [are] relevant to a witness' veracity" (citing Evidence Code section 788). ${ }^{24}$ One inference is that the court now reads section 786 as modifying section 788 . But this is treacherous reasoning: section 788 , enacted concurrently with section $786,{ }^{25}$ specifies four exceptions to its rule, but does not mention section 786. If section 786 estabhishes the bounds for impeachment use of even prior felony convictions, then section 788 is surplusage and was enacted purposelessly. Perhaps Justice Clark's unvarying dissents in the Beagle cases, ${ }^{26}$ attacking the court's "judicial lawmaking," have some force in the context of section 788.

In Woodard, the Beagle line of cases has progressed to a point where section 788 has no vitality, although it may be inentioned-and quickly disposed of-in briefs and opinions. In its place, section 786 allows character impeachment only for veracity, and Woodard teaches that felony convictions do not necessarily indicate dishonesty in a witness, despite the legislature's apparent intention generally to let in evidence of such convictions for impeachment purposes.

21. 6 Cal. 3d at 453,492 P.2d at 8, 99 Cal. Rptr. at 320 .

22. CAL. Evid. Code $\$ 786$ (West 1966).

23. 23 Cal. 3d at 335, 590 P.2d at 394, 152 Cal. Rptr. at 539.

24. $10 \mathrm{Cal} .3 \mathrm{~d}$ at $540,516 \mathrm{P} .2 \mathrm{~d}$ at $874,111 \mathrm{Cal}$. Rptr. at 170.

25. CAL. Evid. Code $\S \S 786,788$ (West 1966).

26. $23 \mathrm{Cal}$. 3d at 344, 590 P.2d at 400,152 Cal. Rptr. at 545 (dissenting opinion); People v. Rist, 16 Cal. 3d at 223, 545 P.2d at 842, 127 Cal. Rptr. at 466 (Clark, J., joining dissent); People v. Antik, 15 Cal. 3d at 100, 599 P.2d at 57, 123 Cal. Rptr. at 489 (Clark, J., joining dissent). 